\title{
Dongsha Atoll is an important stepping-stone that promotes regional genetic connectivity in the South China Sea
}

\author{
Shang Yin Vanson Liu ${ }^{\text {Corresp., }, 2, \text { Jacob Green }^{3,4} \text {, Dana Briggs }}{ }^{3}$, Ruth Hastings ${ }^{3}$, Ylva Jondelius ${ }^{3}$, Skylar Kensinger ${ }^{3,5}$ \\ , Hannah Leever ${ }^{3}$, Sophia Santos ${ }^{3}$, Trevor Throne ${ }^{3}$, Chi Cheng ${ }^{2}$, Hawis Madduppa ${ }^{6}$, Robert J. Toonen ${ }^{7}$, Michelle \\ R. Gaither ${ }^{8}$, Eric D. Crandall ${ }^{\text {Corresp. } 3,9}$ \\ ${ }^{1}$ Dongsha Atoll Research Station, College of Marine Sciences, National Sun Yat-sen University, Kaohsiung City, Taiwan \\ 2 Department of Marine Biotechnology and Resources, National Sun Yat-Sen University, Kaohsiung City, Taiwan \\ 3 School of Natural Sciences, California State University, Monterey Bay, California, United States \\ 4 Department of Biological and Environmental Science, University of Rhode Island, Kingston, Rhode Island, United States \\ 5 Department of Molecular, Cellular and Developmental Biology, University of California, Santa Cruz, Santa Cruz, California, United States \\ 6 Department of Marine Science and Technology, Institut Pertanian Bogor, Bogor, Indonesia \\ 7 Hawai'i Institute of Marine Biology, University of Hawai'i at Mānoa, Kane'ohe, Hawai'i, United States \\ 8 Department of Biology, University of Central Florida, Orlando, Florida, United States \\ 9 Department of Biology, Pennsylvania State University, University Park, Pennsylvania, United States \\ Corresponding Authors: Shang Yin Vanson Liu, Eric D. Crandall \\ Email address: syvliu@mail.nsysu.edu.tw, ecrandall@psu.edu
}

Background Understanding region-wide patterns of larval connectivity and gene flow is crucial for managing and conserving marine biodiversity. Dongsha Atoll National Park (DANP), located in the northern South China Sea (SCS), was established in 2007 to study and conserve this diverse and remote coral atoll. However, the role of Dongsha Atoll in connectivity throughout the SCS is seldom studied. In this study, we aim to evaluate the role of DANP in conserving regional marine biodiversity.

Methods In total 206 samples across nine marine species were collected and sequenced from Dongsha Atoll, and these data were combined with available sequence data from each of these nine species archived in the Genomic Observatories Metadatabase (GEOME). Together these data provide the most extensive population genetic analysis of a single marine protected area. We evaluate metapopulation structure for each species by using a coalescent sampler, selecting among panmixia, stepping-stone, and island models of connectivity in a likelihood-based framework. We then completed a heuristic graph theoretical analysis based on maximum dispersal distance to get a sense of Dongsha's centrality within the SCS.

Results Our dataset yielded 111 unique haplotypes across all taxa at DANP, 58\% of which were not sampled elsewhere. Analysis of metapopulation structure showed that five out of nine species have strong regional connectivity across the SCS such that their gene pools are effectively panmictic (mean pelagic larval duration (PLD) $=78$ days, $s d=60$ days); while four species have stepping-stone metapopulation structure, indicating that larvae are exchanged primarily between nearby populations (mean PLD = 37 days, sd = 15 days). For all but one species, Dongsha was ranked within the top 15 out of 115 large reefs in the South China Sea for betweenness centrality. Thus, for most species, Dongsha Atoll provides an essential link for maintaining stepping-stone gene flow across the SCS.

Conclusions This multispecies study provides the most comprehensive examination of the role of Dongsha Atoll in marine connectivity in the South China Sea to date. Combining new and existing 
population genetic data for nine coral reef species in the region with a graph theoretical analysis, this study provides evidence that Dongsha Atoll is an important hub for sustaining connectivity for the majority of coral-reef species in the region. 
1 Dongsha Atoll is an important stepping-stone that promotes regional genetic

2

3

4

\section{connectivity in the South China Sea}

\section{Authors:}

Shan-Yin Vanson Liu ${ }^{1,2, *}$, Jacob Green ${ }^{3,4}$, Dana Briggs ${ }^{3}$, Ruth Hastings ${ }^{3}$, Ylva Jondelius ${ }^{3}$, Skylar Kensinger $^{3,5}$, Hannah Leever ${ }^{3}$, Sophia Santos ${ }^{3}$, Trevor Throne ${ }^{3}$, Chi Cheng ${ }^{1,2}$, Hawis Madduppa $^{6}$, Robert J. Toonen ${ }^{7}$, Michelle R. Gaither ${ }^{8}$, Eric D. Crandall ${ }^{3,9, *}$.

\section{Affiliations:}

${ }^{1}$ Dongsha Atoll Research Station, College of Marine Sciences, National Sun Yat-sen University, Taiwan.

${ }^{2}$ Department of Marine Biotechnology and Resources, National Sun Yat-sen University, Kaohsiung 804, Taiwan

${ }^{3}$ School of Natural Sciences, California State University, Monterey Bay, Seaside, CA, 93955, USA

${ }^{4}$ Department of Biological and Environmental Science, University of Rhode Island, Kingston, Rhode Island, USA

${ }^{5}$ Department of Molecular, Cellular and Developmental Biology, University of California, Santa Cruz, California, USA

${ }^{6}$ Department of Marine Science and Technology, Faculty of Fisheries and Marine Sciences, Institut Pertanian Bogor (IPB University), Bogor, Indonesia

${ }^{7}$ Hawai' 'i Institute of Marine Biology, University of Hawai'i at Mānoa; Kane'ohe, Hawai' $i$, USA.

${ }^{8}$ Department of Biology, University of Central Florida; Orlando, Florida, USA

${ }^{9}$ Department of Biology, Pennsylvania State University; University Park, Pennsylvania, USA

* corresponding author

Keywords: Indo-Pacific, migration models, larval dispersal, marine connectivity, phylogeography, marine metapopulations, stepping-stones

Running Title: Dongsha Atoll As A Stepping-Stone 
35

36

37

38

39

40

41

42

43

44

45

46

47

48

49

50

51

52

53

54

55

56

57

58

59

60

61

62

63

64

65

66

67

68

69

70

71

72

73

74

75

76

77

78

79

\section{Abstract}

Background

Understanding region-wide patterns of larval connectivity and gene flow is crucial for managing and conserving marine biodiversity. Dongsha Atoll National Park (DANP), located in the northern South China Sea (SCS), was established in 2007 to study and conserve this diverse and remote coral atoll. However, the role of Dongsha Atoll in connectivity throughout the SCS is seldom studied. In this study, we aim to evaluate the role of DANP in conserving regional marine biodiversity.

Methods

In total 206 samples across nine marine species were collected and sequenced from Dongsha Atoll, and these data were combined with available sequence data from each of these nine species archived in the Genomic Observatories Metadatabase (GEOME). Together these data provide the most extensive population genetic analysis of a single marine protected area. We evaluate metapopulation structure for each species by using a coalescent sampler, selecting among panmixia, stepping-stone, and island models of connectivity in a likelihood-based framework. We then completed a heuristic graph theoretical analysis based on maximum dispersal distance to get a sense of Dongsha's centrality within the SCS.

Results

Our dataset yielded 111 unique haplotypes across all taxa at DANP, $58 \%$ of which were not sampled elsewhere. Analysis of metapopulation structure showed that five out of nine species have strong regional connectivity across the SCS such that their gene pools are effectively panmictic (mean pelagic larval duration (PLD) $=78$ days, $s d=60$ days); while four species have stepping-stone metapopulation structure, indicating that larvae are exchanged primarily between nearby populations (mean PLD $=37$ days, $\mathrm{sd}=15$ days). For all but one species, Dongsha was ranked within the top 15 out of 115 large reefs in the South China Sea for betweenness centrality. Thus, for most species, Dongsha Atoll provides an essential link for maintaining stepping-stone gene flow across the SCS.

Conclusions

This multispecies study provides the most comprehensive examination of the role of Dongsha Atoll in marine connectivity in the South China Sea to date. Combining new and existing population genetic data for nine coral reef species in the region with a graph theoretical analysis, this study provides evidence that Dongsha Atoll is an important hub for sustaining connectivity for the majority of coral-reef species in the region.

\section{Introduction}

With coral reefs and their communities in accelerating global decline (Hughes et al., 2003; 2018), governments around the world have established Marine Protected Areas (MPAs) as a way to counteract this trend (Selig \& Bruno, 2010). It is now quite clear that MPAs, especially when planned as part of a network, can increase biodiversity, enhance the biomass of fished species, and promote ecosystem resilience (Emslie et al., 2015; Mellin et al., 2016; Sala et al. 2021). When properly sized and spaced, a network of MPAs can protect coral reef populations, and an adequate fraction of their larval offspring that disperse to nearby MPAs, ensuring both long-term community persistence and fisheries spillover (Gaines et al., 2010; Krueck et al. 2017).

However, while there are a few robust examples of MPA networks planned at the regional level 
80 (Gleason et al., 2013; Emslie et al., 2015), most MPAs are singletons implemented by regional

81

82

83

84

85

86

87

88

89

90

91

92

93

94

95

96

97

98

99

100

101

102

103

104

105

106

107

108

109

110

111

112

113

114

115

116

117

118

119

120

121

122

123

124

125 governments for local benefit only (Gaines et al., 2010).

Singleton MPAs are still valuable for the conservation and resilience of local coral reef communities and maintaining local fisheries through larval export and adult spillover (Lester et al., 2009; Mellin et al., 2016). However, it remains crucial to evaluate, post hoc, their role in conserving regional marine biodiversity. Does the MPA serve as a useful intergenerational stepping-stone that can augment demographic and genetic connectivity among regional reefs (McCook et al., 2009)? Coalescent samplers are a family of population genetic models that allow a relatively quick and inexpensive way to make such an evaluation (Crandall, Treml \& Barber, 2012; Selkoe et al., 2016; Crandall et al., 2019b). In a likelihood-based model selection framework, such methods can distinguish between models of effective panmixia (high regional gene flow) and metapopulation models in which larvae disperse only to nearby populations (stepping-stone model) or to all sampled populations (island model; Beerli \& Palczewski, 2010).

Understanding the role of a given MPA in region-wide connectivity patterns requires genetic data from many species from inside the MPA and from the surrounding populations. Fortunately, a working group of the Diversity of the Indo-Pacific Network has compiled a genetic database comprising over 38,000 individuals from more than 230 species (DIPnet; Crandall et al., 2019a), stored within the Genomic Observatories Metadatabase (GEOME; Deck et al., 2017; Riginos et al., 2020). This open database provides the opportunity to test various biogeography, speciation, and connectivity hypotheses across a wide taxonomic swath of species comprising Indo-Pacific communities, without the need to sample every location and every species by a single research group.

Located $340 \mathrm{~km}$ southeast of Hong Kong and $850 \mathrm{~km}$ southwest of Taipei, Dongsha Atoll, with an area of about $600 \mathrm{~km}^{2}$, is the largest and oldest atoll in the South China Sea (SCS; Fig. 1), (Dai, 2004). The atoll is of strategic political importance in that it sits in the Taiwan Strait, a major trade route between East and Southeast Asia. The atoll also hosts important coral reef habitats in the northern South China Sea, providing necessary fishing opportunities for the people of China, Taiwan, and Vietnam (Dai, 2004). For this reason, the Dongsha Atoll National Park (DANP) was established in 2004 by the Taiwanese government. The DANP encompasses $3,537 \mathrm{~km}^{2}$ of marine habitat (Cheng et al., 2020), and its establishment has helped to mitigate the impact of massive bleaching events in 1998 and overfishing at the atoll, which were negatively impacting coral cover and biodiversity (Fang, 1998; Soong, Dai \& Lee, 2002; Dai 2004). With proper enforcement and regional cooperation in place since 2007, a general survey of marine resources in the DANP in 2011 showed that both terrestrial and marine ecological resources are gradually recovering (Dai 2012). Contradicting these results, Cheng et al. (2020) detected a dramatic 34\% decrease in coral coverage since the DANP was established, with an alarming reduction in the abundance of branching corals indicating an overall simplification of habitat types. Although the effect of the establishment of the DANP on community biodiversity and health is still under debate, how these conservation efforts might have impacted other reefs in the South China Sea and beyond is poorly understood.

In the present study, we added sequence data from nine coral reef species sampled within the DANP to existing datasets in GEOME to test metapopulation hypotheses regarding the role of 
126 each species' Dongsha population in the greater context of the Indo-Pacific. We then used a

127 graph theoretical analysis based on maximum dispersal distances to more closely examine

128 Dongha's role as an intergenerational stepping-stone within the South China Sea.

129

130

131

132

133

134

135

136

137

138

139

140

141

142

143

144

145

146

147

148

149

150

151

152

153

154

155

156

157

158

159

160

161

162

163

164

165

166

167

168

169

170

171

\section{Materials \& Methods}

\section{Sampling and Sequencing}

We selected nine target species from the Genomic Observatories Metadatabase (GEOME; Deck et al., 2017) based on the availability of genetic data from nearby populations and their common occurrence at Dongsha Atoll, including eight reef fishes and the intertidal gastropod Nerita plicata (Table 1). In March of 2017, tissue samples for these nine species were collected at Dongsha by SCUBA divers using spears in the case of reef fish species, or by hand in the case of the gastropod. Tissues were preserved in $95 \%$ ethanol. The field sampling of the present study is under the permit number 0000691 which was approved by the Marine National Park Headquarters in Taiwan.

Mitochondrial DNA (mtDNA) amplification and sequencing were conducted at California State University Monterey Bay as part of the Molecular Ecology and Evolution capstone research course in Fall of 2017. Marker choice was made based on the data available in GEOME and included the mitochondrial Cytochrome Oxidase I, Cytochrome-B, and the Control Region. In each case, published primers were used (see Table 1 for details). DNA was extracted in a $10 \%$ Chelex ${ }^{\circledR}$ (Biorad) solution following Walsh et al. (1991). Polymerase chain reactions (PCR) were conducted in $25 \mu \mathrm{L}$ reactions with $2.5 \mu \mathrm{L}$ of $10 x$ PCR buffer, $2 \mu \mathrm{L} \mathrm{MgCl}_{2}(25 \mathrm{mM}), 2.5 \mu \mathrm{L}$ dNTPs $(8 \mathrm{mM})$, $1.25 \mu \mathrm{L}$ of each $10 \mathrm{mM}$ primer, $1 \mu \mathrm{L}$ of DNA template, and $0.625 \mathrm{U}$ of AmpliTaq (Applied Biosystems). Thermocycling conditions were the same across species, only differing in annealing temperature: initial denature for $2 \mathrm{~min}$ at $95^{\circ} \mathrm{C}$; followed by 35 cycles of denaturation at $95^{\circ} \mathrm{C}$ for $15 \mathrm{~s}$; annealing at $\mathrm{T}^{\circ} \mathrm{C}$ for $30 \mathrm{~s}$ (where $\mathrm{T}$ is given in Table 1); and elongation at $72^{\circ} \mathrm{C}$ for $1 \mathrm{~min}$; with a final elongation step at $72^{\circ} \mathrm{C}$ for 7 min. PCR products were checked on a $1 \%$ agarose gel using GelRed (Biotium). Successful PCR products were sent to the MCLab (South San Francisco; mclab.com) for cleanup, cycle sequencing (both directions), and sequencing on an ABI 3730 DNA Sequencer. Forward and reverse reads for each sample were proofread and aligned using Geneious 9.1.8 software. Complementary sequence data from four or five nearby populations were downloaded for each species from the GEOME database (Fig. 1). Sequences for each species were aligned and trimmed to a common length using the muscle algorithm with default parameters implemented in Geneious v9 (Biomatters) and exported to FASTA format.

\section{Population Genetic Analysis}

We used the pegas (Paradis, 2010) and strataG (Archer, Adams \& Schneiders, 2017) population genetic packages to read the FASTA-formatted data into R and identify unique haplotypes. We then utilized these packages to estimate standard genetic diversity statistics for the Dongsha population of each species. Haplotype diversity and the number of haplotypes unique to Dongsha were calculated using the exptdHet, privateAlleles functions in strataG. Fu's $\mathrm{F}_{\mathrm{s}}$, a statistic which identifies populations with an excess of recent substitution events caused by demographic 
172 growth, genetic hitchhiking, or background selection (Fu, 1997), was calculated using the fusFS

173 functions in the same package. Nucleotide diversity was measured using the nuc.div function in

174 pegas. The significance of $F_{s}$ was determined with 1,000 coalescent simulations of neutrality in

175 Arlequin 3.5 (Excoffier \& Lischer, 2010). Haplotype diversity, nucleotide diversity, and

176 percentage of private haplotypes (unique to a given population) were also averaged across all

177

178

179

180 nearby sampled populations, and a two-sided t-test was used to determine if the Dongsha populations' genetic diversity was significantly different from the nearest sampled populations.

Pairwise $\Phi_{\mathrm{ST}}$, a sequence analog of $\mathrm{F}_{\mathrm{ST}}$ (Excoffier, Smouse \& Quattro, 1992), was calculated with pairwiseTest in strataG with significance determined by 1,000 randomly drawn permutations of the data to represent the null hypothesis of no genetic structure. Finally, pairwise matrices were visualized in ggplot2 and as non-metric dimensional scaling (NMDS) plots to represent the distances in two-dimensional space using the metaMDSiter function in the $\mathrm{R}$ package vegan (Oksanen et al., 2017), using a hybrid model of monotone and linear regression for $\Phi_{\mathrm{ST}}$ values lower than 0.1 . For both visualizations, negative values were corrected to zero, and for NMDS, zero or negative values had a very small positive value added to them. To visualize whether there is a geographic pattern of haplotype distribution, we defined samples used in this study into six regional groups (Fig. 1). Median joining networks with these regional colors were created using PopArt (Leigh \& Bryant, 2015). All analyses are detailed at https://github.com/ericcrandall/dongsha/.

We also estimated the marginal likelihood of three different metapopulation models for the nine species in Migrate-n 3.6.11 (Beerli \& Felsenstein, 2001; Beerli \& Palczewski, 2010; Fig. 2): (a) extremely high levels of larval dispersal (proportion of migrants $(\mathrm{m})>0.1)$ throughout the sampled range yielding effective panmixia, (b) slightly restricted larval dispersal $(\mathrm{m}<0.1)$ represented by an $n$-island model with equal population sizes and equal migration between all population pairs, (c) restricted larval dispersal such that larvae are only exchanged between neighboring populations or regions as represented in a stepping-stone model (two populations were determined to be neighboring if no other sampled populations would serve as a likely intermediate stepping-stone).

Migrate-n analysis followed methods developed in Crandall et al. (2019b). FASTA-formatted datasets were converted to Migrate-n format using PGDSpider 2.0.5.1 (Lischer \& Excoffier, 2012). For each species, we found optimal parameters (gamma shape parameter, transition transversion ratio and base frequencies) for an HKY $+\mathrm{G}$ model of molecular evolution using the modelTest function in the R package phangorn (Schliep, 2011). The gamma shape parameter was discretized to four categories using the discrete.gamma function from the same package. All models had identical, windowed exponential priors on $\Theta$ (lower bound: $1 \times 10^{-5}$, upper bound: $1 \times 10^{-1}$, mean: 0.01 ) and $\mathrm{m} / \mu$ (lower bound: $1 \times 10^{-4}$, upper bound: $1 \times 10^{6}$, mean: $1 \times 10^{5}$ ) parameters. We used four heated chains with temperatures of $1,1.5,3$, and $1 \times 10^{5}$ to ensure a thorough search of parameter space, thereby enabling an estimate of model marginal likelihood via path sampling (Beerli \& Palczewski, 2010). Migrate-n was set to optimize on the $\mathrm{m} / \mu$ parameter rather than the joint parameter $\mathrm{N}_{\mathrm{e}} \mathrm{m}$ (to avoid correlations with the $\Theta\left(=\mathrm{N}_{\mathrm{e}} \mu\right)$ parameters), and with an inheritance scalar that reflected the haploid, uniparental transmission of mtDNA. For each model, the coolest chain explored fifty million genealogies, sampling every 500 iterations, and discarding the first five million genealogies as burn-in. 
218 Each Migrate-n run comprised three replicates of fifty million genealogies to yield a single estimate

219 of marginal likelihood. Each run was then repeated three times, to yield three independent

220 estimates of metapopulation model marginal likelihood from nine replicate runs. The Bezier-

221 corrected estimate of model marginal likelihood (which approximates the marginal likelihood from

222 a larger number of heated chains) was harvested from each outfile and averaged across the three

223 independent replicate runs. Mean Bezier-corrected marginal likelihoods were converted to relative

224 model probabilities and Bayes factors following Johnson and Omland (2004). To account for

225 variance in mean marginal likelihoods across the three replicate runs, a permutation t-test was run

226 to compare the mean marginal likelihoods of the first and second ranked models, following

227 Crandall et al. (2019b). Parameter files for each species and each model, as well as code for

228 interpreting the output, are available in the Github repository, within the migrate_analysis

229 directory.

230

231

232

233

234

235

236

237

238

239

240

241

242

243

244

245

246

247

248

249

250

251

252

253

254

255

256

257

258

259

260

261

262

263

We then asked to what extent the models selected for each species by Migrate-n were a product of the maximum pelagic larval duration (PLD), especially given the spatially heterogeneous sampling of surrounding populations. Because only two of three possible models were selected by all nine species, we constructed a logistic regression model using values for maximum PLDs from the literature (Table 1) and great-circle distances from Dongsha Atoll to both the nearest and furthest sampled populations for each species, calculated with the Raster package (Hijmans, 2021) in R: $(\mathrm{p}$ (Migrate Model) $\sim$ Maximum PLD + Closest Distance + Furthest Distance). We used backward BIC model selection in the R package MASS (Venables \& Ripley, 2002) to select the best model.

\section{Graph Theoretical Analysis}

To better place our results in the geographical context of the South China Sea, we undertook a graph theoretical analysis of the potential for larval dispersal in this region. We developed two rasters (Fig. 1B) representing 1) coral reef areas and 2) land areas of continents and islands of the South China Sea from Fig. 1 of Zhao et al. (2016) and Fig. 1A of Dorman et al. (2016), and projected both rasters into UTM coordinates (zone $50 \mathrm{~N}$ ) with $1 \mathrm{~km}$ resolution using the raster package. We then imported these rasters into Graphab 2.6 (Foltête, Clauzel \& Vuidel, 2012), defining the reef areas with at least 25 hectares as habitat patches, and the land areas as a cost raster with each pixel costing 10,000. Graphab then generated a linkset between reef patches for each species using a maximum dispersal distance calculated as the product of maximum PLD (Table 1) and the mean current speed of $18.7 \mathrm{~km} /$ day given by Hu et al. (2000). The basic binary simple (undirected) graph generated by Graphab from this linkset was then imported into the igraph package for R (Csardi \& Nepusz), which we used to measure betweenness centrality, defined as the fraction of shortest paths between all patches which pass through a given reef patch. Estrada and Bodin (2008) have shown that betweenness centrality is an important measure of the overall importance of a patch to the large-scale connectivity of a landscape. We also used igraph to measure the diameter of each species' graph, as the minimum number of larval-dispersal steps connecting the two most distant points. It is important to emphasize that this approach is not equivalent to a biophysical model of larval dispersal such as found in Dorman et al. (2016), and most dispersal is expected to occur at much shorter distances (Cowen et al. 2000). However, since genetic structure is very sensitive to dispersal at the tails of the larval dispersal kernel (Grosberg \& Cunningham, 2001), this approach might provide an approximate understanding of potential gene flow in the South China Sea. 


\section{Results}

We sequenced a total of 206 tissue samples from Dongsha across the nine species. Sequence length varied from 316 bp (Control Region, Ctenochaetus striatus) to $1058 \mathrm{bp}$ (Cytochrome-B, Dascyllus aruanus). A total of 111 unique haplotypes across all nine species were detected (Table 2). Within our dataset, 58\% of these haplotypes were apparently private to Dongsha Atoll (at least within the local region sampled from GEOME), ranging from 5\% in the oval butterflyfish Chaetodon lunulatus to $\sim 80 \%$ in the whorled nerite Nerita plicata and the striated surgeonfish Ctenochaetus striatus. The bluestripe snapper Lutjanus kasmira had significantly elevated genetic diversity ( $h, \pi$ and \% private alleles) at Dongsha compared to the rest of the region; however, this may be an artifact of low sample size. The neon damselfish Pomacentrus coelestis had significantly lower genetic diversity $(\mathrm{h}, \pi$, and $\%$ private alleles) at Dongsha than the surrounding populations. All but three species had Fu's $\mathrm{F}_{\mathrm{S}}$ values that were significantly negative at the recommended alpha of $\mathrm{p}<0.02(\mathrm{Fu}, 1997)$, indicating a departure from neutrality due to an excess of recent mutations at the tips of the genealogy. Median-joining haplotype networks showed no clear geographic pattern of haplotype distribution for any species (Fig. 3). In addition, all haplotype networks showed a star-like topology providing visual confirmation of the low Fu's $F_{S}$ values and evidence of either recent natural selection or population expansion. The combined data set used in this study has been shared with location and date metadata in GEOME (geome-db.org) within the "Reef Species of Dongsha Atoll" expedition of the Diversity of the Indo-Pacific Project, with GUID: https://n2t.net/ark:/21547/Dos2. By clicking "Query All Reef Species of Dongsha Atoll Samples", the fasta file can be downloaded through the download option next to "map" option.

Pairwise $\Phi_{\mathrm{ST}}$ values varied from 0 (found in every dataset) to 0.202 in different taxa across IndoPacific (Supplemental Fig. S1). In the Japanese surgeonfish, Acanthurus japonicas significant genetic structures were found between Okinoerabu (near Okinawa Island), Philippines, and Xisha. In addition, the Dongsha population of L. kasmira was highly and significantly structured with all other populations. However, low sample size in the Okinoerabu population of $A$. japonicus $(\mathrm{n}=6)$ and the Dongsha population of L. kasmira $(\mathrm{n}=6)$ curtails our ability to interpret the significance of these observations of high $\Phi_{\mathrm{ST}}$. The only other significant value of $\Phi_{\text {ST }}(0.077)$ for a Dongsha population was with the Xisha Islands in the whitetail dascyllus, Dascyllus aruanus. On average, the Dongsha population of each species had 1.9 positive pairwise $\Phi_{\mathrm{ST}}$ values out of a total of 3 or 4 populations that it was measured against. Due to the lack of co-sampling of each species at these other sites, there were no clear geographic patterns in Dongsha's genetic structuring with other populations. NMDS plots (Supplemental Fig. S2) generally showed a similar lack of correlation with geography, except for perhaps $C$. striatus and C. lunulatus. This general lack of geographic signal in genetic structure is a common feature in the Indo-Pacific (Gaither et al. 2011, Crandall et al., 2019a) and marine population genetic datasets in general (Selkoe \& Toonen, 2011; Selkoe et al., 2016).

Relative probabilities for each of three metapopulation models tested by Migrate-n are depicted in Fig. 4. Following guidelines laid out by Kass and Raftery (1995), Migrate-n found strong support for a metapopulation model wherein the Dongsha population acts as an important regional stepping-stone for oval butterflyfish (Chaetodon lunulatus; $5.42 \times 10^{9}: 1$ odds against panmixia; see Table 3), striated surgeonfish (Ctenochaetus striatus; $1.78 \times 10^{8}: 1$ odds against 
310 panmixia; see Table 3, Fig. 4), and substantial support for a stepping-stone model in the 311 pearlscale angelfish (Centropyge vroliki; 12:1 odds against panmixia). The whitetail damselfish

312 (Dascyllus aruanus) had modest support for a stepping-stone model (4:1 odds against panmixia),

313 but the mean log-likelihood for this model was not significantly higher than that for panmixia ( $p$

$314=0.15$ ), leaving this result ambiguous. Datasets from the five other species strongly and

315 unambiguously supported a regional model of effective panmixia (Table 3).

316

317

318

319

320

321

322

323

324

325

326

327

328

329

330

331

332

333

334

335

336

337

338

339

340

341

342

343

344

345

346

347

348

349

350

351

352

353

354

355

Backward stepwise model selection found that maximal and minimal distances between Dongsha and other sampled populations were not important predictors of whether Migrate-n selected a stepping-stone model. Maximum PLD was the only important predictor in explaining when Migrate-n selected a stepping-stone model over panmixia, with an improvement of 4.12 units of log-likelihood between the full model and one with PLD only. The resultant model was significant $(\mathrm{p}=0.0473)$, with the coefficient indicating that for every day increase in PLD, there is a $9.3 \%$ decrease in the odds of selecting a stepping-stone model $(95 \% \mathrm{CI}: 0.002 \%-23 \%$; Fig. 5).

Graphab found 115 reef patches greater than 25 hectares in the South China Sea. These patches were connected with a minimum graph diameter of one larval dispersal step (Nerita plicata) or a maximum of 7 generational steps for Dascyllus aruanus (Fig. 6). Graph diameter was highly correlated with PLD $\left(\mathrm{r}^{2}=0.61\right)$, so we do not present a separate logistic regression for its ability to predict whether a species had a stepping-stone model. Out of 115 reef patches, Dongsha was always ranked in the top 15 reef patches for betweenness centrality, ranging from the $3^{\text {rd }}$ most important reef (Chaetodon lunulatus and Pomacentrus coelestis) and the $14^{\text {th }}$ most important reef (Dascyllus aruanus) for this metric. The only reefs with consistently higher rankings were found in the Xisha Islands, the Zhongsha Islands, and Huangyan Island (Fig. 6).

\section{Discussion}

While this genetic analysis of nine coral reef species represents a relatively small proportion of the thousands of species comprising the Dongsha Atoll National Park community, it is also the most extensive analysis attempted to put a protected single reef community into the broader ecological and evolutionary context of the Indo-Pacific to date. Overall, our analysis indicates that over evolutionary timescales, Dongsha populations are well-connected with the rest of the South China Sea and indeed with the rest of the Indo-Pacific and maintain genetic diversities that do not significantly deviate from average (except for $P$. coelestis, see discussion below). Furthermore, for marine species with mean PLDs less than 40 days (the vast majority; Strathman, 1987; Shanks, 2009), Dongsha Atoll provides a valuable stepping-stone that is consistently within the top 15 reef patches for promoting regional genetic and demographic connectivity within the South China Sea (Fig. 5 and 6).

Genetic population structure between Dongsha Atoll and nearby populations, as measured by the sequence-based $\mathrm{F}_{\mathrm{ST}}$ analog $\Phi_{\mathrm{ST}}$, was generally low and non-significant (Fig. S1). This finding is congruent with the results of connectivity studies targeting damselfishes between the SCS and Kuroshio regions which showed low and non-significant genetic structure among the Xisha (Paracel) Islands, Dongsha, and Taiwan (Liu et al., 2011, Liu et al., 2014, Liu et al., 2018). Failure to reject panmixia is generally common in marine species (Waples, 1998; Kinlan \& Gaines 2003),

Peer] reviewing PDF | (2021:04:60091:2:0:NEW 3 Aug 2021) 
356 has been found consistently in the Indo-Pacific (Keyse et al. 2014; Crandall et al., 2019a), and is 357 traditionally interpreted as evidence for relatively high levels of gene flow due to larval dispersal. 358 However, these summary statistics can often be zero even when there has not been gene flow in 359 thousands of generations (Faurby \& Barber 2012; Crandall et al., 2019a), and they do not provide

360

361

362

363

364

365

366

367

368

369

370

371

372

373

374

375

376

377

378

379

380

381

382

383

384

385

386

387

388

389

390

391

392

393

394

395

396

397

398

399

400

401

any information about metapopulation structure.

Five of the nine species surveyed here demonstrate strong regional connectivity in the South China Sea such that their gene pools are well-mixed (effective panmixia; mean SCS graph diameter for these species $=3.0$ intergenerational dispersal events, $s d=1.22$ ). In contrast, the coalescent approach employed here clearly distinguishes these from the four species that have some regional metapopulation structure (stepping-stone; Table 3, Fig. 4). This latter group generally has shorter PLDs (mean PLD $=37$ days, $s d=15$ days) than the former group (mean PLD $=78$ days, $s d=60$ days), meaning that it will take more generations to cross the SCS (mean SCS graph diameter for these species $=5.25$ intergenerational dispersal events, $s d=1.70$ ). For these shorter PLD species, Dongsha Atoll provides an important intergenerational stepping-stone for maintaining gene flow across the SCS (highly ranked betweenness centrality for all species except $N$. plicata; Fig. 6). Furthermore, Fig. 5 demonstrates a significant relationship between PLD and metapopulation structure (albeit with wide confidence intervals) with a sharply increasing probability that a species will have a metapopulation structure that relies on Dongsha Atoll as PLD decreases to about 40 days or less. Below, we discuss the oceanographic context of the SCS as it relates to our findings.

\section{Oceanographic circulation patterns in the SCS and larval dispersal}

The seasonal circulation patterns in the SCS are mainly driven by monsoon winds and comprise several cyclonic/anticyclonic eddies. In contrast, northeastward monsoons and southwestward monsoons prevail during winter and summer, respectively (Hu et al. 2000, Fig. 1B). During winter, most currents are northeastward and turn east of Natuna Islands toward the west coast of Luzon in the Philippines. Meanwhile, the Kuroshio intrusion splits into two currents, with one branch moving toward Dongsha and another toward Xisha Islands (Paracel Islands), then turns northward to pass along the Taiwan coast. During summer, most of the currents flow southwestward, with a mean current velocity of $18.7 \mathrm{~km} / \mathrm{day}$, while the southwestward monsoon weakens the Kuroshio Intrusion.

Given this circulation pattern, Fig. 6 provides heuristic estimates of the maximum dispersal distances for larvae of each species during the summer, when most corals and fish are spawning (Liu, 2011; Ho, 2017). For example, even larvae from the species with the shortest PLD (Dascyllus aruanus; 26 days) should be able to drift to the nearest reefs $230 \mathrm{~km}$ away near Hong Kong, or to Taiwan, $433 \mathrm{~km}$ away (D. aruanus; Fig. 1B and 6). In contrast, species with the longest PLD (Nerita plicata; 180 days) should be able to reach anywhere in the SCS in a single larval dispersal event. These estimates are heuristic because the vast majority of larvae released at Dongsha or elsewhere will not be advected over the maximal distance due to diffusion and mortality (Cowen et al. 2000). On the other hand, it is possible that larvae may occasionally be advected beyond the depicted maximum distance by infrequent events such as typhoons or by the extension of their larval duration beyond what has been measured (McCormick 1999). In the present study, Zongsha seems to act as an important hub for the connectivity in the area between Xisha, Zhongsha and Huangyang Island as revealed in Fig. 6. Liu et al. (2020) suggested that the seasonal dynamic of

Peer) reviewing PDF | (2021:04:60091:2:0:NEW 3 Aug 2021) 
402 eddies may facilitate the dispersal of marine organisms in this area which may support the role of 403 Zongsha in term of population connectivity. However, the heuristic estimates in Fig. 1B and 6 are 404 useful in showing that, in general, the species for which a stepping-stone model of metapopulation

405

406

407

408

409

410

411

412

413

414

415

416

417

418

419

420

421

422

423

424

425

426

427

428

429

430

431

432

433

434

435

436

437

438

439

440

441

442

443

444

445

446

structure was selected are only able to reach neighboring reefs, while those for which panmixia was selected have the capacity to disperse widely in the SCS and beyond.

Moreover, more sophisticated biophysical modeling of larval dispersal in the South China Sea indicates a clear regional structure for species with a PLD of 40 days or less (Melbourne-Thomas et al. 2011; Dorman et a., 2016; Liu et al., 2020). Although focused on the central and southern SCS, Melbourne-Thomas et al. (2011) modeled particles with 30 or 40 day PLD, active or passive dispersal with a rate of mortality of 0.1 to 0.2 per day, and showed that all particles released from the Nansha Islands (i.e., Spratly or Kalayaan islands) settled either in the Nanshas or in western Palawan. Using more particles, slightly more realistic biological parameters, and tracking particles released from the Nanshas for 90 days or until settlement, Dorman et al. (2016) got similar results, with most particles staying in the Nanshas or moving eastward to Palawan, but they also showed limited connectivity from the Nanshas to the Xishas and Northern Luzon, especially during the Fall when currents shift to the northeast. Finally, Liu et al. (2020) simulated benthic currents at 200-400 $\mathrm{m}$ depth over 60 days to show little connectivity between deep-sea coral (Deltocyathus magnificus) populations near Dongsha and the Xisha Islands, which was confirmed by clear genetic structure in microsatellites.

The significant relationship between PLD and the existence of metapopulation structure demonstrated here (Fig. 5) has wide confidence intervals due to two species. A metapopulation model of effective panmixia was selected for the neon damselfish, Pomacentrus coelestis despite having a maximum PLD of 39 days, while a stepping-stone model was most probable for $C$. striatus, even though it has a maximum PLD of 59 days (Wilson \& McCormick 1999). Although the best model for explaining metapopulation structure did not include sampling distance as a factor, we suggest that heterogeneous sampling may have played a role in the models that were selected for at least these two species. The nearest sampled population to Dongsha for the $P$. coelestis dataset was $411 \mathrm{~km}$ away in Taiwan, while the furthest was 1,304 km away in Okinawa. Furthermore, the fact that the Dongsha sample of $P$. coelestis deviated from average regional diversities suggests that our sample of this species may be non-representative. The low genetic diversities in Table 2 may be due to cohesive dispersal among related larvae (Robitzch et al. 2020) since the specimens that we collected were juveniles around the same size and collected at the same location. Therefore, the haplotypes identified from these samples may derive from a relatively small number of parents. For $C$. striatus, even the nearest sampled population was much further than Okinawa, 2,280 km away in Bunaken near Sulawesi, while the furthest sampled population was 3,217 km away near Krakatau in the Sunda Strait. Given these heterogeneous sampling distances and the possibly non-representative sample of $P$. coelestis, it is easier to understand how a stepping-stone model was inferred over large distances for $C$. striatus while a model of panmixia was selected over short distances for $P$. coelestis. Future efforts to comparatively model metapopulation structure should standardize sampling to the extent that it is possible.

\section{Conclusions}

PeerJ reviewing PDF | (2021:04:60091:2:0:NEW 3 Aug 2021) 
447 For the relatively low cost of adding mitochondrial sequence data from nine coral reef species 448 sampled within the national park at Dongsha Atoll to existing datasets we were able to successfully 449 test metapopulation hypotheses of larval dispersal and gene flow for each of these reef species. 450 While it is important to acknowledge that these results derive from only a single genetic locus, 451

\section{References}

Archer FI, Adams PE, Schneiders BB. 2017. STRATAG: An R package for manipulating, summarizing and analysing population genetic data. Molecular Ecology Resources 17:5-11. DOI: 10.1111/1755-0998.12559.

Baensch, F. 2014. The Hawaii Larval Fish Project. Coral 11(2): 64-77.

Beerli P, Palczewski M. 2010. Unified Framework to Evaluate Panmixia and Migration Direction Among Multiple Sampling Locations. Genetics 185:313-326. DOI: 10.1534/genetics.109.112532. 
484 Bowen BW, Shanker K, Yasuda N, Celia M, Malay MC, von der Heyden S, Paulay G, Rocha

485

486

487

488

489

490

491

492

493
LA, Selkoe KA, Barber PH, Williams ST, Lessios HA, Crandall ED, Bernardi G, Meyer

CP, Carpenter KE, Toonen RJ. 2014. Phylogeography unplugged: comparative surveys in the genomic era. Bulletin Of Marine Science 90:13-46. DOI: 10/gfrkbr.

Cheng Y-R, Chin C-H, Lin D-F, Wang C-K. 2020. The Probability of an Unrecoverable Coral Community in Dongsha Atoll Marine National Park Due to Recurrent Disturbances. Sustainability 12:9052. DOI: 10/gjj2vk.

Cowen RK, Lwiza KM, Sponaugle S, Paris CB, Olson DB. 2000. Connectivity of marine populations: open or closed? Science 287:857-859. DOI: 10/b6vj5w.

Crandall ED, Riginos C, Bird CE, Liggins L, Treml E, Beger M, Barber PH, Connolly SR, Cowman PF, DiBattista JD, Eble JA, Magnuson SF, Horne JB, Kochzius M, Lessios HA, Liu SYV, Ludt WB, Madduppa H, Pandolfi JM, Toonen RJ, Contributing Members of the Diversity of the Indo-Pacific Network, Gaither MR. 2019a. The molecular biogeography of the Indo-Pacific: Testing hypotheses with multispecies genetic patterns. Global Ecology And Biogeography 58:403-418. DOI: 10/ggvsdc.

Crandall ED, Toonen RJ, ToBo Laboratory, Selkoe KA. 2019b. A coalescent sampler successfully detects biologically meaningful population structure overlooked by Fstatistics. Evolutionary Applications 12:255-265. DOI: 10.1111/eva.12712.

Crandall ED, Treml EA, Barber PH. 2012. Coalescent and biophysical models of stepping-stone gene flow in neritid snails. Molecular Ecology 21:5579-5598. DOI: 10/f4dvqs.

Csardi G, Nepusz T. 2006. The igraph software package for complex network research. Interjournal. Complex Systems. 1695. https://igraph.org

Dai C. 2004. Dong-sha Atoll in the South China Sea: Past, Present and Future. In: Changing 
Islands - Changing Worlds. Kinmen Island, Taiwan, 10.

508 Dai CF. 2012. Natural Resources and Management Strategy Analysis of Dongsha Atoll Natural

509 Park, Marine National Park Headquarters: Kaohsiung, Taiwan. (In Chinese)

510 Dorman JG, Castruccio FS, Curchitser EN, Kleypas JA, Powell TM. 2016. Modeled connectivity

511 of Acropora millepora populations from reefs of the Spratly Islands and the greater South

512 China Sea. Coral Reefs 35(1): 169-179.

513 DiBattista JD, Berumen ML, Gaither MR, Rocha LA, Eble JA, Choat JH, Craig MT, Skillings

DJ, Bowen BW. 2013. After continents divide: comparative phylogeography of reef

515 fishes from the Red Sea and Indian Ocean. Journal Of Biogeography 40:1170-1181.

516 DOI: 10/ggvr9d.

517 DiBattista JD, Waldrop E, Bowen BW, Schultz JK, Gaither MR, Pyle RL, Rocha LA. 2012. Twisted sister species of pygmy angelfishes: discordance between taxonomy, coloration, and phylogenetics. Coral Reefs 31:839-851.

DiBattista JD, Waldrop E, Rocha LA, Craig MT, Berumen ML, Bowen BW. 2015. Blinded by the bright: a lack of congruence between colour morphs, phylogeography and taxonomy for a cosmopolitan Indo-Pacific butterflyfish, Chaetodon auriga. Journal o $\mathrm{f}$ Biogeography 42:1919-1929. DOI: 10/ggvscz.

DiBattista JD, Whitney J, Craig MT, Hobbs J-PA, Rocha LA, Feldheim KA, Berumen ML, Bowen BW. 2016. Surgeons and suture zones: Hybridization among four surgeonfish species in the Indo-Pacific with variable evolutionary outcomes. Molecular Phylogenetics And Evolution 101:203-215. DOI: 10.1016/j.ympev.2016.04.036. 
530 Deck J, Gaither MR, Ewing R, Bird CE, Davies N, Meyer C, Riginos C, Toonen RJ, Crandall

531 ED. 2017. The Genomic Observatories Metadatabase (GeOMe): A new repository for

532 field and sampling event metadata associated with genetic samples. PLoS Biology

533 15:e2002925. DOI: 10.1371/journal.pbio.2002925.

534 Emslie MJ, Logan M, Williamson DH, Ayling AM, MacNeil MA, Ceccarelli D, Cheal AJ,

535 Evans RD, Johns KA, Jonker MJ, Miller IR, Osborne K, Russ GR, Sweatman HPA.

536 2015. Expectations and Outcomes of Reserve Network Performance following Re-zoning

537 of the Great Barrier Reef Marine Park. Current Biology 25:983-992. DOI: 10/f688pk.

538 Estrada E, Bodin Ö. 2008. Using Network Centrality Measures to Manage Landscape

539 Connectivity. Ecological Applications 18:1810-1825. DOI: 10/cgt76n.

540 Faurby S, Barber PH. 2012. Theoretical limits to the correlation between pelagic larval duration

$541 \quad$ and population genetic structure. Molecular Ecology 21(14): 3419-3432.

542 Folmer O, Black M, Hoeh W, Lutz R, Vrijenhoek R. 1994. DNA primers for amplification of

543 mitochondrial cytochrome c oxidase subunit I from diverse metazoan invertebrates.

544 Molecular Marine Biology and Biotechnology 3:294-299

545 Foltête J-C, Clauzel C, Vuidel G. 2012. A software tool dedicated to the modelling of landscape

546 networks. Environmental Modelling \& Software 38:316-327. DOI: 10/f4bjvp.

547 Fu YX. 1997. Statistical tests of neutrality of mutations against population growth, hitchhiking

$548 \quad$ and background selection. Genetics 147:915-925.

549 Gaines SD, White C, Carr MH, Palumbi SR. 2010. Designing marine reserve networks for both

550 conservation and fisheries management. Proceedings Of The National Academy Of

551 Sciences Of The United States Of America-Biological Sciences 107:18286-18293. DOI:

$552 \quad 10.1073 /$ pnas.0906473107. 
553 Gaither MR, Toonen RJ, Robertson DR, Planes S, Bowen BW. 2010. Genetic evaluation of

554 marine biogeographical barriers: perspectives from two widespread Indo-Pacific snappers

555 (Lutjanus kasmira and Lutjanus fulvus). Journal Of Biogeography 37:133-147. DOI:

$556 \quad 10 / \operatorname{cxj9v7.}$

557 Gaither MR, Jones SA, Kelley C, Newman SJ, Sorenson L, Bowen BW. 2011. High connectivity

558 in the deepwater snapper Pristipomoides filamentosus (Lutjanidae) across the Indo-

559 Pacific with isolation of the Hawaiian Archipelago. PLoS One, 6, doi:

$560 \quad 10.1371$ journal.pone.0028913.

561 Gleason M, Fox E, Ashcraft S, Vasques J, Whiteman E, Serpa P, Saarman E, Caldwell M,

562 Frimodig A, Miller-Henson M, Kirlin J, Ota B, Pope E, Weber M, Wiseman K. 2013.

563 Designing a network of marine protected areas in California: Achievements, costs, lessons learned, and challenges ahead. Ocean \& Coastal Management 74:90-101. DOI:

566 Grosberg RK, Cunningham CW. 2001. Genetic Structure in the Sea: From Populations to Communities. Marine Population Ecology:1-24.

568 Hijmans RJ. 2021. raster: Geographic Data Analysis and Modeling. R package.

569 Ho Y-N. 2017. Larval fish assemblages in the lagoon of Dongsha Atoll, Master Thesis, $570 \quad$ National Sun Yat-sen University

571 Hu J, Kawamura H, Hong H, Qi Y. 2000. A review on the currents in the South China Sea: seasonal circulation, South China Sea warm current and Kuroshio intrusion. Journal of Oceanography 56(6): 607-624.

574

575

576
Hughes TP, Baird AH, Bellwood DR, Card M, Connolly SR, Folke C, Grosberg R, HoeghGuldberg O, Jackson JBC, Kleypas J, Lough JM, Marshall P, Nystrom M, Palumbi SR, 
577

578

579

580

581

582

583

584

585

586

587

588

589

590

591

592

593

594

595

596

597

598

599

Pandolfi JM, Rosen B, Roughgarden J. 2003. Climate change, human impacts, and the resilience of coral reefs. Science 301:929-933.

Hughes TP, Kerry JT, Baird AH, Connolly SR, Dietzel A, Eakin CM, Heron SF, Hoey AS, Hoogenboom MO, Liu G, McWilliam MJ, Pears RJ, Pratchett MS, Skirving WJ, Stella JS, Torda G. 2018. Global warming transforms coral reef assemblages. Nature 556:492496. DOI: 10/cngq.

Kass RE, Raftery AE. 1995. Bayes Factors. Journal Of The American Statistical Association 90:773-795. DOI: 10/gdnbw3.

Keyse J, Crandall ED, Toonen RJ, Meyer CP, Treml EA, Riginos C. 2014. The scope of published population genetic data for Indo-Pacific marine fauna and future research opportunities in the region. Bulletin of Marine Science. 90(1):47-78.

Kinlan BP, Gaines SD. 2003. Propagule dispersal in marine and terrestrial environments: a community perspective. Ecology. 84(8): 2007-2020.

Krueck NC, Ahmadia GN, Green A, Jones GP, Possingham HP, Riginos C, Treml EA, Mumby PJ. 2017. Incorporating larval dispersal into MPA design for both conservation and fisheries. Ecological applications 27(3): 925-941.

Lee WJ, Conroy J, Howell WH, Kocher TD. 1995. Structure and Evolution of Teleost Mitochondrial Control Regions. Journal of Molecular Evolution 41: 54-66.

Lester S, Halpern B, Grorud-Colvert K, Lubchenco J, Ruttenberg B, Gaines S, Airamé S, Warner R. 2009. Biological effects within no-take marine reserves: a global synthesis. Marine Ecology Progress Series 384:33-46. DOI: 10/dqzt2n.

Liu S-T. 2011. Studies on the factors which restrict acroporids recovering in the lagoon of Dongsha Atoll, Master Thesis, National Sun Yat-sen University 
600 Liu SYV, Wang CH, Shiao JC, Dai CF. 2011. Population connectivity of neon damsel,

601 Pomacentrus coelestis, inferred from otolith microchemistry and mtDNA. Marine and

$602 \quad$ Freshwater Research 61(12): 1416-1424.

603 Liu SYV, Dai CF, Allen GR, Erdmann MV. 2012. Phylogeography of the neon damselfish

604 Pomacentrus coelestis indicates a cryptic species and different species origins in the West

605 Pacific Ocean. Marine Ecology Progress Series. 458:155-167.

606

607 Liu SYV, Chang FT, Borsa P, Chen WJ, Dai CF. 2014. Phylogeography of the humbug

608

609

damselfish, Dascyllus aruanus (Linnaeus, 1758): evidence of Indo-Pacific vicariance and

610 genetic differentiation of peripheral populations. Biological Journal of the Linnean Society 113(4): 931-942.

611 Liu SYV, Tuanmu MN, Rachmawati R, Mahardika GN, Barber PH. 2019. Integrating phylogeographic and ecological niche approaches to delimitating cryptic lineages in the blue-green damselfish (Chromis viridis). PeerJ 7: e7384.

614 Liu SYV, Hsin YC, Cheng YR. 2020. Using particle tracking and genetic approaches to infer population connectivity in the deep-sea scleractinian coral Deltocyathus magnificus in the South China sea. Deep Sea Research Part I: Oceanographic Research Papers 161: 103297.

618 McCook L, Almany GR, Berumen ML, Day J, Green AL, Jones GP, Leis JM, Planes S, Russ GR, Sale PF, Sale PF, Thorrold SR. 2009. Management under uncertainty: guide-lines for incorporating connectivity into the protection of coral reefs. Coral Reefs 28:353-366.

621 DOI: $10 /$ df4fp9.

McCormick MI. 1999. Delayed metamorphosis of a tropical reef fish (Acanthurus triostegus): a field experiment. Marine Ecology Progress Series 176:25-38. DOI: 10/cgfz38. 
624 Melbourne-Thomas J, Johnson CR, Alino PM, Geronimo RC, Villanoy CL, Gurney GG. 2011. A

625

626

627

628

630

631

632

633

634

635

636

637

638

639

640

641

642

643

644

645

646

multi-scale biophysical model to inform regional management of coral reefs in the western Philippines and South China Sea. Environmental Modelling and Software 26(1): 66-82.

Mellin C, MacNeil MA, Cheal AJ, Emslie MJ, Caley MJ. 2016. Marine protected areas increase resilience among coral reef communities. Ecology Letters 19:629-637. DOI: 10/f8k6mb.

Met Office. 2014. Cartopy: a cartographic python library with a Matplotlib interface. https://scitools.org.uk/cartopy.

Palumbi SR, Martin AP, Romano S, Mcmilan WO, Stice L, Grabowski G. 1991. The simple fool's guide to PCR. University of Hawaii.

Paradis E. 2010. pegas: an R package for population genetics with an integrated-modular approach. Bioinformatics 26:419-420. DOI: 10.1093/bioinformatics/btp696.

Riginos C, Crandall ED, Liggins L, Gaither MR, Ewing RB, Meyer C, Andrews KR, Euclide PT, Titus BM, Therkildsen NO, Salces-Castellano A, Stewart LC, Toonen RJ, Deck J. 2020. Building a global genomics observatory: Using GEOME (the Genomic Observatories Metadatabase) to expedite and improve deposition and retrieval of genetic data and metadata for biodiversity research. Molecular Ecology Resources 20:1458-1469. DOI: 10/ghf4wp.

Robitzch V, Saenz-Agudelo P, Berumen ML. 2020. Travel with your kin ship! Insights from genetic sibship among settlers of a coral damselfish. Ecology and evolution 10(15): 82658278.

Rossi V, Ser-Giacomi E, López C, Hernández-García E. 2014. Hydrodynamic provinces and oceanic connectivity from a transport network help designing marine reserves.

Peer] reviewing PDF | (2021:04:60091:2:0:NEW 3 Aug 2021) 
647

648

649

650

651

652

653

654

655

656

657

658

659

660

661

662

663

664

665

666

667

668

669

Geophysical Research Letters 41(8): 2883-2891.

Sala E, Mayorga J, Bradley D, Cabral RB, Atwood TB, Auber A, Cheung W, Costello C, Ferretti F, Friedlander AM, Gaines SD, Garilao C, Goodell W, Halpern BS, Hinson A, Kaschner K, Kesner-Reyes K, Leprieur F, McGowan J, Morgan LE, Mouillot D, Palacios-Abrantes J, Possingham HP, Rechberger KD, Worm B, Lubchenco J. 2021. Protecting the global ocean for biodiversity, food and climate. Nature 592:397-402. DOI: 10/gig8qd.

Selig ER, Bruno JF. 2010. A Global Analysis of the Effectiveness of Marine Protected Areas in Preventing Coral Loss. PLOS ONE 5:e9278. DOI: 10/dzk6jw.

Selkoe KA, Toonen RJ. 2011. Marine connectivity: a new look at pelagic larval duration and genetic metrics of dispersal. Marine Ecology Progress Series 436:291-305. DOI: 10.3354/meps09238.

Selkoe KA, D'Aloia CC, Crandall ED, Iacchei M, Liggins L, Puritz JB, von der Heyden S, Toonen RJ. 2016. A decade of seascape genetics: contributions to basic and applied marine connectivity. Marine ecology progress series. Oldendorf 554:1-19. DOI: 10/gdf36m.

Shanks AL. 2009. Pelagic Larval Duration and Dispersal Distance Revisited. Biological Bulletin 216:373-385.

Strathman MF. 1987. Reproduction and Development of Marine Invertebrates of the Northern Pacific Coast. University of Washington Press.

Treml EA, Halpin PN, Urban DL, Pratson LF. 2008. Modeling population connectivity by ocean currents, a graph-theoretic approach for marine conservation. Landscape Ecology 23(1): 

19-36.

671 Venables WN, Ripley BD. 2002. Modern Applied Statistics. Springer, New York: Modern $672 \quad$ Applied Statistics with S.

673 Waples RS. 1998. Separating the wheat from the chaff: Patterns of genetic differentiation in high 674 gene flow species. Journal Of Heredity 89:438-450. DOI: 10/ck5gf8.

675 Waldrop E, Hobbs J-PA, Randall JE, DiBattista JD, Rocha LA, Kosaki RK, Berumen ML, 676 Bowen BW. 2016. Phylogeography, population structure and evolution of coral-eating 677 butterflyfishes (Family Chaetodontidae, genus Chaetodon, subgenus Corallochaetodon). 678 Journal of Biogeography 43:1116-1129. DOI: 10/f8s88q.

679

680 Zhao M, Yu K, Shi Q, Yang H, Riegl B, Zhang Q, Yan H, Chen T, Liu G, Lin Z. 2016. The coral 681 communities of Yongle atoll: status, threats and conservation significance for coral reefs

682 in South China Sea. Marine and Freshwater Research 67:1888. DOI: 10/f9fs7b.

683

684

685

686

687

688

689

690

691

692

693

694

695

696

697

698 
699 Fig. 1. A) Map of all sampled locations. Outer rings are colored by which species were sampled 700 at a locality, while inner circles are keyed to regional colors in Fig. 3. B) Inset of South China

701 Sea showing coral reefs in red following Zhao et al. (2016) and Dorman et al. (2016). Summer

702 surface circulation patterns (solid line with arrows; winter circulation is roughly reversed) and

703 Kuroshio Current intrusion (dotted line with arrows) follow Hu et al. (2000). Open circles are

704 colored by species, and give estimates of maximum larval dispersal distances given mean

705 summer surface current speed of $18.7 \mathrm{~km} /$ day (Hu et al. 2000) and PLDs given in Table 1. Solid

706 circles indicate species for which a stepping-stone model was selected, and dashed lines indicate

707 species for which panmixia was selected. Maps were generated from the public domain Natural

708 Earth raster with the Cartopy v0.11.2 package for Python (Met Office, 2014).

709

710 Figure 2. Visualization of all metapopulation models tested for each species. Black lines below

711 each species name indicate a distance of $1,000 \mathrm{~km}$. Blue text indicates sampled sites which are

712 arranged in geographic space. Dotted lines with arrows connect every pair of sample sites and

713 indicate directional migration (gene flow) parameters included in the n-island model while solid

714 lines with arrows indicate directional migration parameters included in the stepping-stone model.

715 The model of panmixia treated all sampled localities as a single population.

716

717

718

719

720

721

722

723

724

725

726

727

728

729

730

731

732

733

734

735

736

737

738

739

740

741

742

Figure 3. Median-joining networks for all nine species. Each circle represents a haplotype, with the frequency of the haplotype indicated by the circle's size (scale varies across species). Pie charts indicate each haplotype's distribution across sampling sites. Lines indicate possible mutational changes between haplotypes, with hash marks representing more than one change.

Figure 4. Relative probability of each of four metapopulation hypotheses depicted in Figure 2 for each of nine species sampled at Dongsha as calculated from Migrate-n marginal likelihoods averaged across three replicate runs.

Figure 5. Logistic regression model for: Migrate-n model maximum PLD, with $95 \%$ confidence intervals constructed as $1.96 \mathrm{x}$ standard error. Model is shown between 20 and 70 days larval duration to avoid extrapolation. Black circles show species with datasets that selected a stepping-stone model, while open circles show species datasets that selected a model of effective panmixia.

Figure 6. Undirected binary simple graphs between 115 South China Sea reef patches with areas greater than 25 hectares. Circle sizes are proportional to the approximate reef area of each patch, while darker colors indicate a higher relative betweenness centrality for a given patch. Blue triangles indicate a genetic sample for that species. Yellow lines show shortest overwater paths between reef patches that could potentially be connected by larval dispersal assuming a maximum distance given in the lower right corner. Additional statistics in the lower right corner include pelagic larval duration (PLD), graph diameter (D) as the shortest number of larval dispersal event required to cross the longest distance between reef patches for a given species and the ranking of betweenness centrality $(\mathrm{BC})$ for Dongsha out of 115 reef patches. Genetic data for species with underlined names supported a stepping-stone model of dispersal. 


\section{Figure 1}

Sampling map

A) Map of all sampled locations. Outer rings are colored by which species were sampled at a locality, while inner circles are keyed to regional colors in Fig. 3. B) Inset of South China Sea showing coral reefs in red following Zhao et al. ( 2016 ) and Dorman et al. ( 2016 ) . Summer surface circulation patterns (solid line with arrows; winter circulation is roughly reversed) and Kuroshio Current intrusion (dotted line with arrows) follow Hu et al. ( 2000 ). Open circles are colored by species, and give estimates of maximum larval dispersal distances given mean summer surface current speed of $18.7 \mathrm{~km} /$ day (Hu et al. 2000) and PLD s given in Table 1. Solid circles indicate species for which a stepping-stone model was selected, and dashed lines indicate species for which panmixia was selected. Maps were generated from the public domain Natural Earth raster with the Cartopy v0.11.2 package for Python (Met Office, 2014).

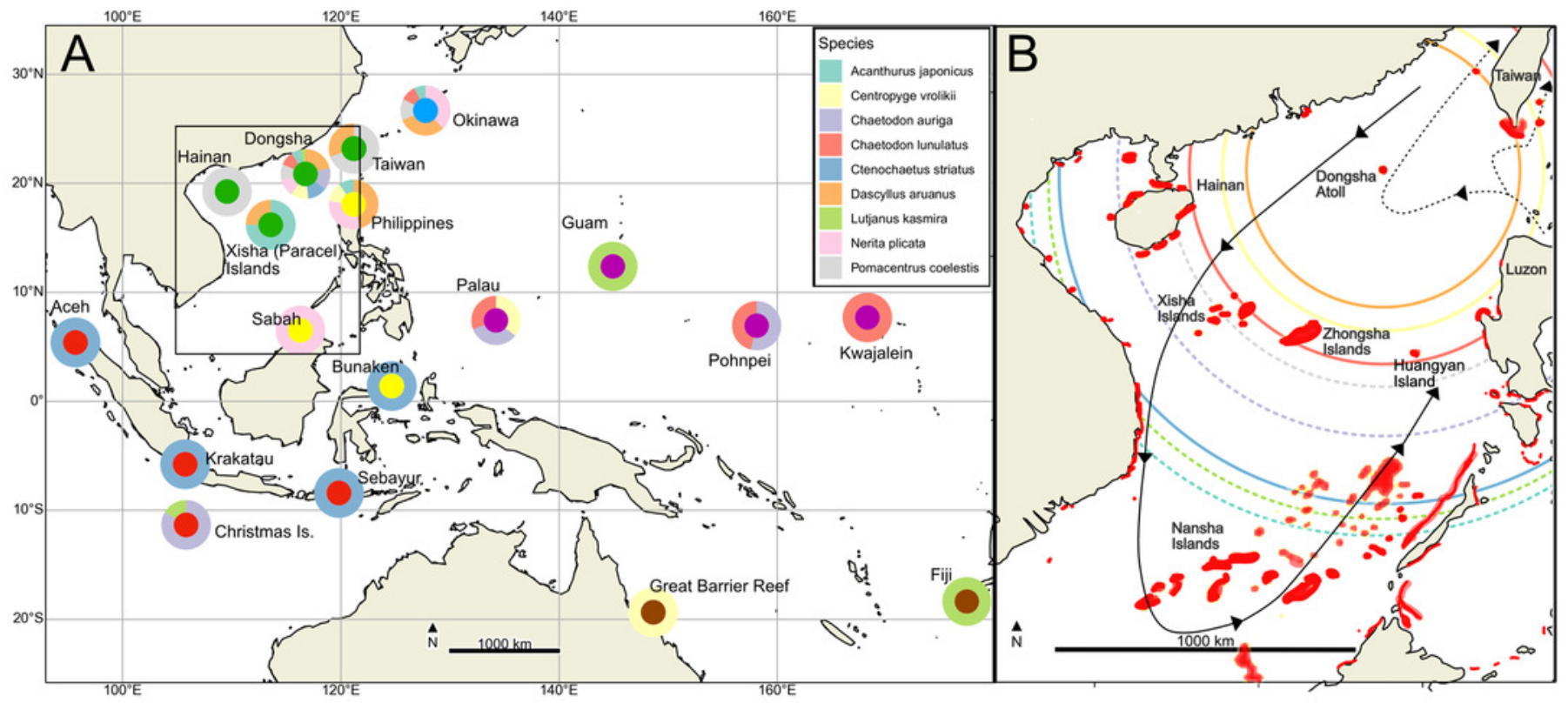




\section{Figure 2}

Visualization of all metapopulation models tested for each species.

Visualization of all metapopulation models tested for each species. Black lines below each species name indicate a distance of $1,000 \mathrm{~km}$. Blue text indicates sampled sites which are arranged in geographic space. Dotted lines with arrows connect every pair of sample sites and indicate directional migration (gene flow) parameters included in the n-island model while solid lines with arrows indicate directional migration parameters included in the stepping-stone model. The model of panmixia treated all sampled localities as a single population. 


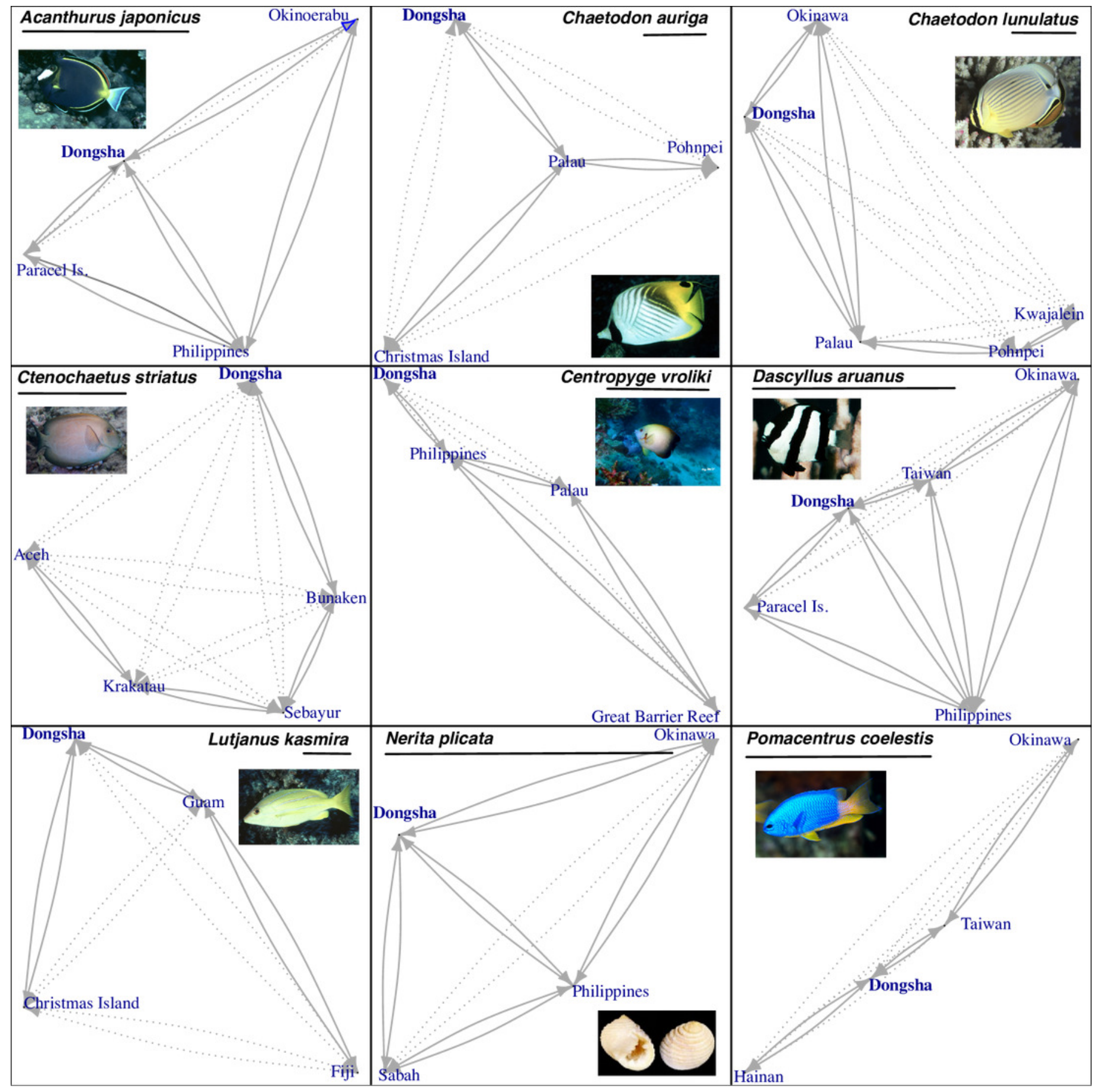




\section{Figure 3}

Haplotype networks of nine species.

Median-joining networks for all nine species. Each circle represents a haplotype, with the frequency of the haplotype indicated by the circle's size (scale varies across species). Pie charts indicate each haplotype's distribution across sampling sites. Lines indicate possible mutational changes between haplotypes, with hash marks representing more than one change. 
Acanthurus japonicus (CytB)

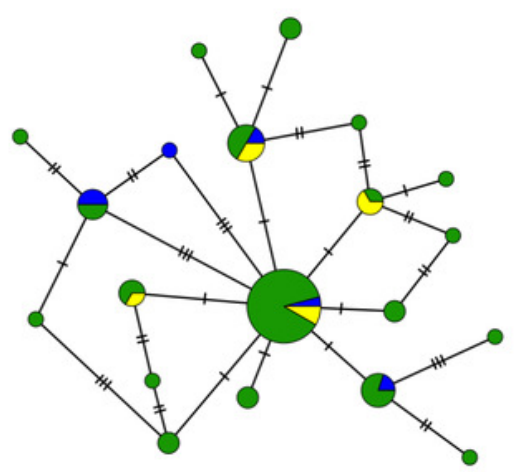

Ctenochaetus striatus (CR)
Chaetodon auriga (CytB)

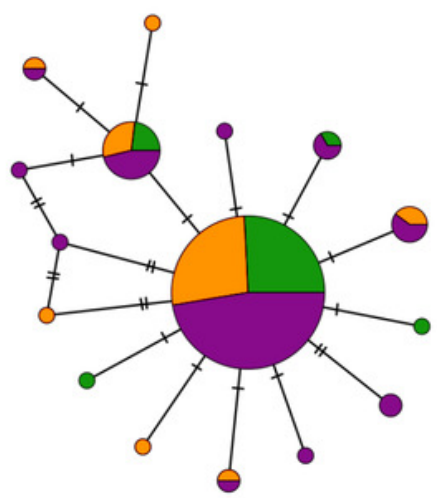

Centropyge vroliki (CytB)
Chaetodon Iunulatus (CytB)

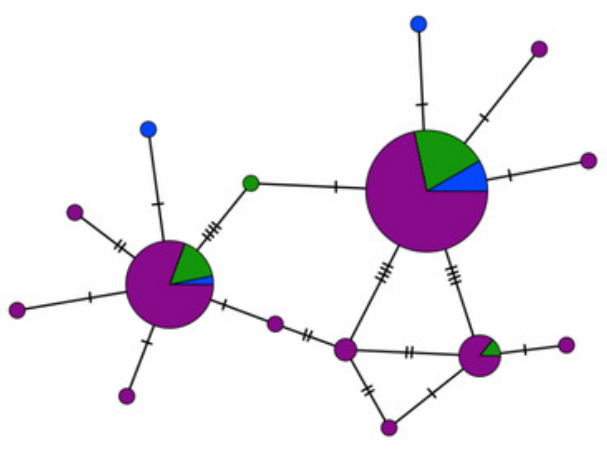

Dascyllus aruanus (Cyt B)

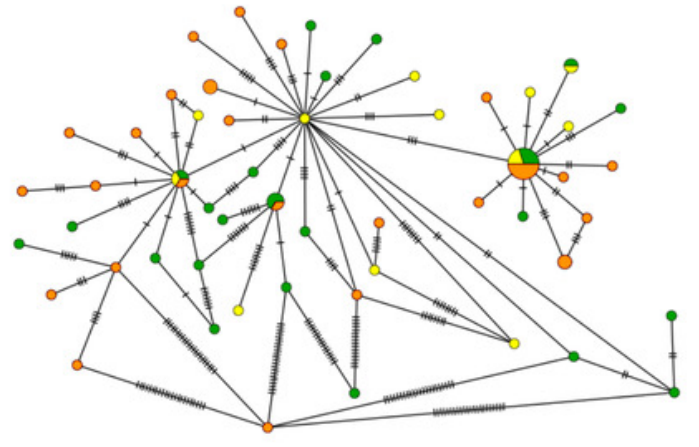

Lutjanus kasmira (CytB)

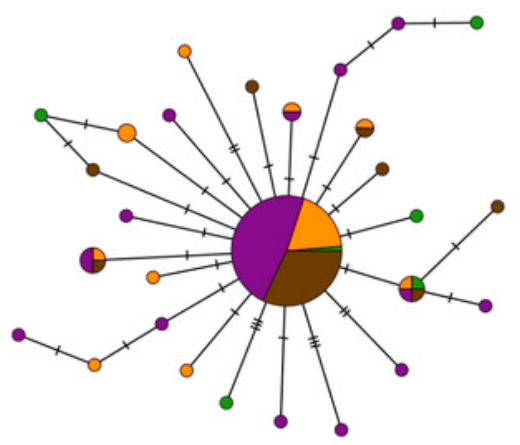

Nerita plicata (CO1)

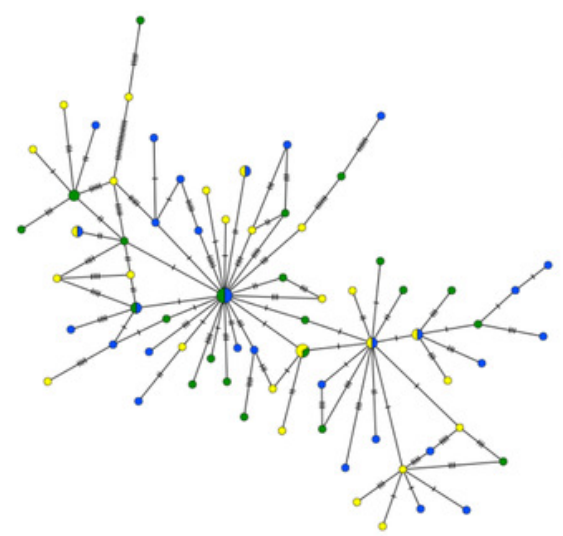

Pomacentrus coelestis (CR)

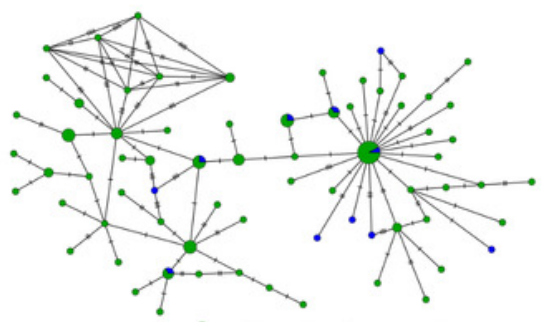

South China Sea

Okinawa

Philippines

Indonesia \& Malaysia

Western Pacific

Australia 


\section{Figure 4}

Relative probability of each of four metapopulation hypotheses.

Relative probability of each of four metapopulation hypotheses depicted in Figure 2 for each of nine species sampled at Dongsha as calculated from Migrate-n marginal likelihoods averaged across three replicate runs.

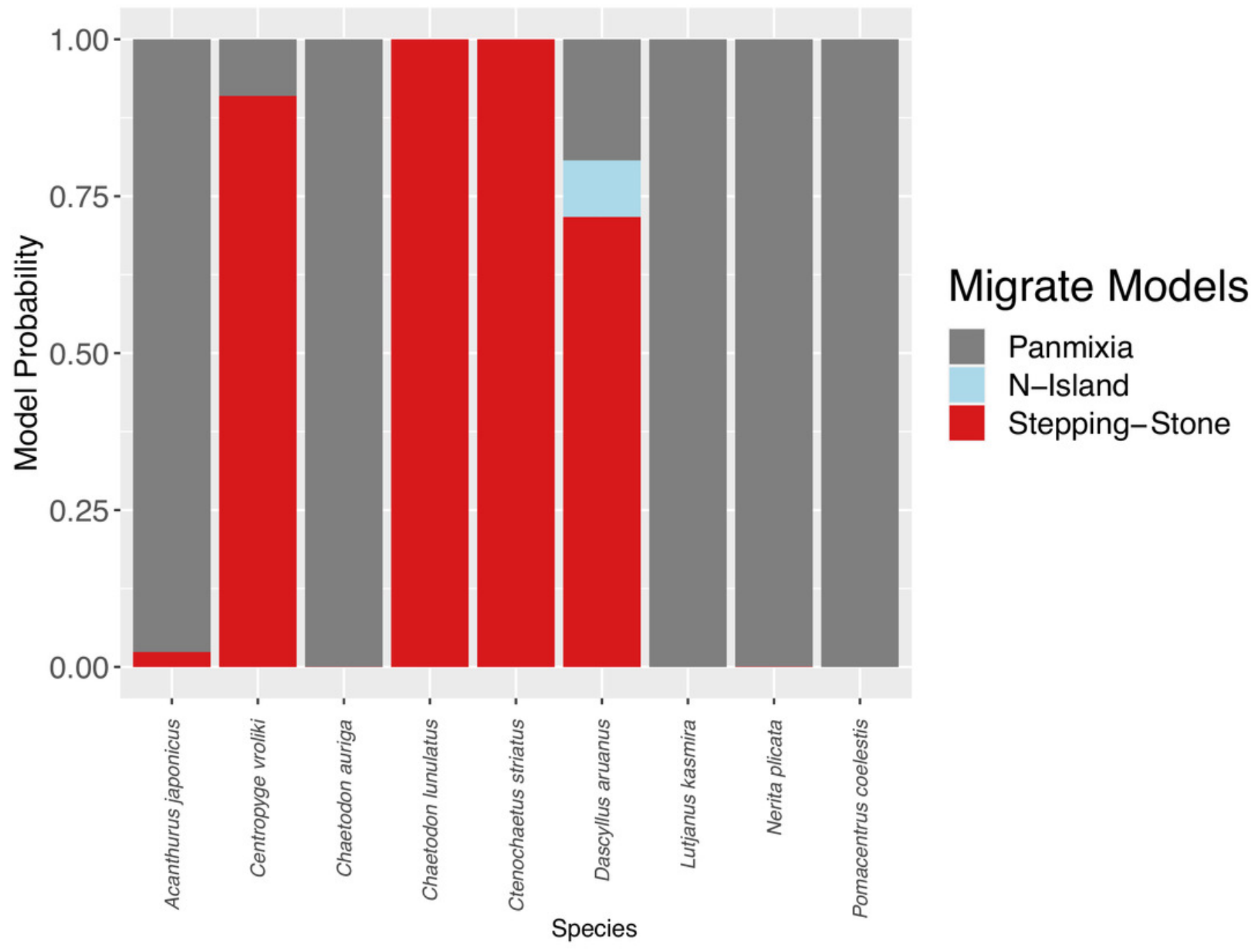




\section{Figure 5}

Logistic regression model.

Logistic regression model for: Migrate-n model maximum PLD , with $95 \%$ confidence intervals constructed as $1.96 \times$ standard error. Model is shown between 20 and 70 days larval duration to avoid extrapolation. Black circles show species with datasets that selected a stepping-stone model, while open circles show species datasets that selected a model of effective panmixia.

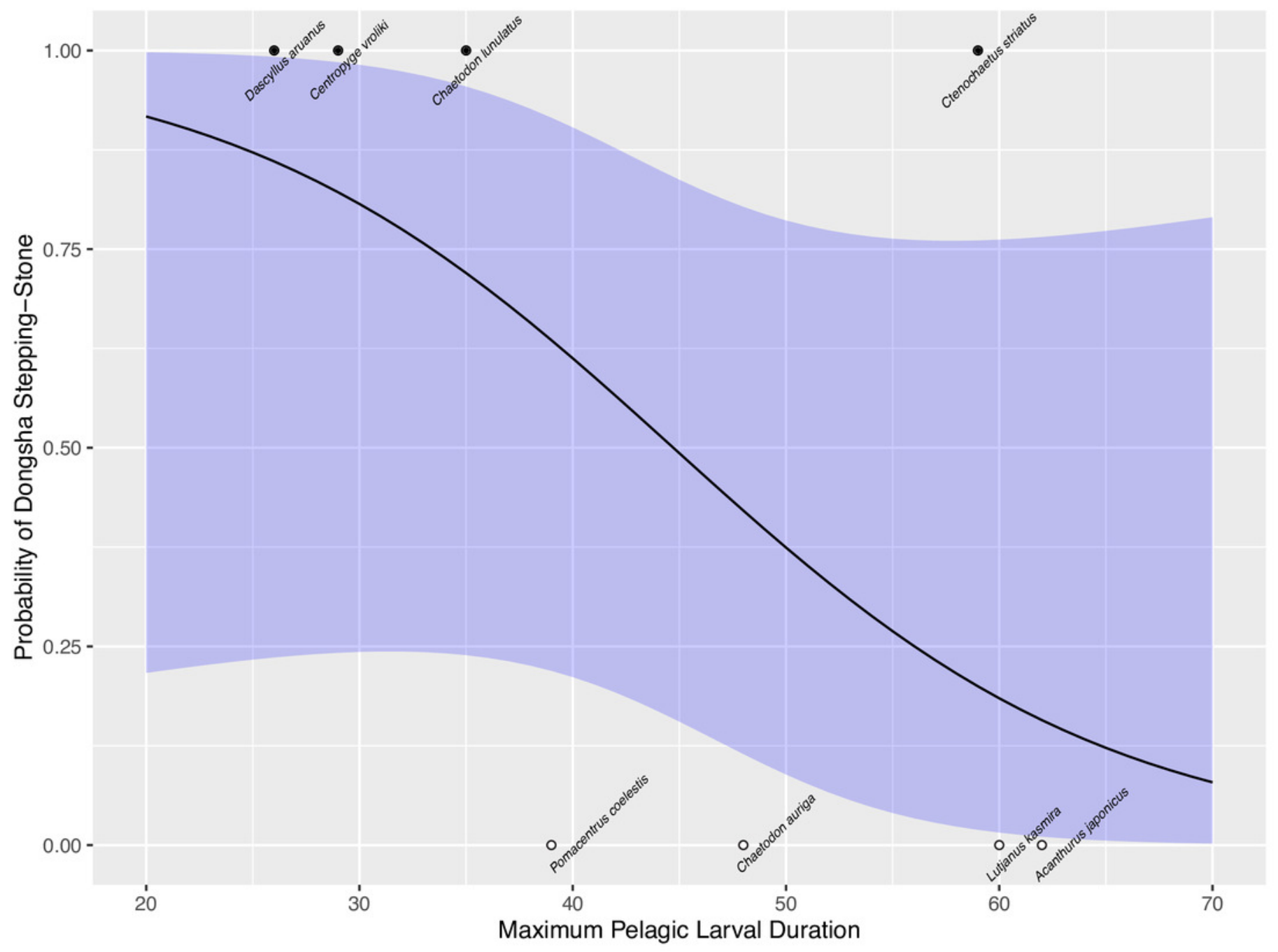




\section{Figure 6}

Figure 6

Undirected binary simple graphs between 115 South China Sea reef patches with areas greater than 25 hectares. Circle sizes are proportional to the approximate reef area of each patch, while darker colors indicate a higher relative betweenness centrality for a given patch. Blue triangles indicate a genetic sample for that species. Yellow lines show shortest overwater paths between reef patches that could potentially be connected by larval dispersal assuming a maximum distance given in the lower right corner. Additional statistics in the lower right corner include pelagic larval duration (PLD), graph diameter (D) as the shortest number of larval dispersal event required to cross the longest distance between reef patches for a given species and the ranking of betweenness centrality (BC) for Dongsha out of 115 reef patches. Genetic data for species with underlined names supported a stepping-stone model of dispersal. 

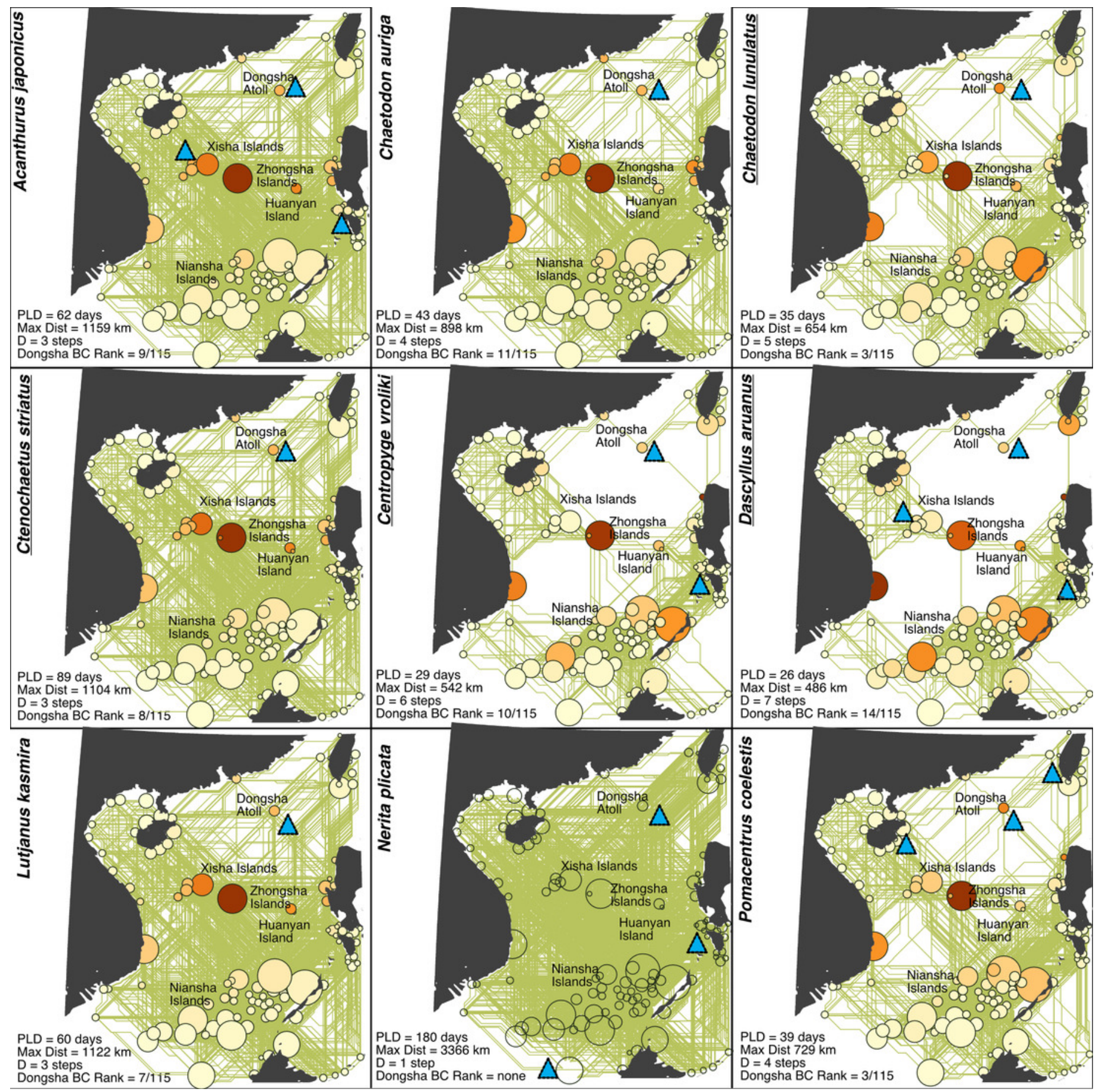


\section{Table 1 (on next page)}

Table 1. Species names, estimated pelagic larval durations, and primers and annealing temperatures used for PCR. 
Table 1. Species names, estimated pelagic larval durations, and primers and annealing temperatures used for PCR.

\begin{tabular}{|c|c|c|c|c|}
\hline $\begin{array}{l}\text { Scientific } \\
\text { name } \\
\text { (Dataset } \\
\text { Citation) }\end{array}$ & $\begin{array}{l}\text { Common } \\
\text { name }\end{array}$ & $\begin{array}{l}\text { Maximum } \\
\text { Pelagic Larval } \\
\text { Duration } \\
\text { (days) }\end{array}$ & $\begin{array}{l}\text { mtDNA Locus (base pairs) } \& \\
\text { Primers used }\end{array}$ & $\begin{array}{l}\text { Annealing } \\
\text { Temp }\left({ }^{\circ} \mathrm{C}\right)\end{array}$ \\
\hline $\begin{array}{l}\text { Acanthurus } \\
\text { japonicus } \\
\text { (DiBattista et } \\
\text { al., 2016) }\end{array}$ & $\begin{array}{l}\text { Japanese } \\
\text { surgeonfish }\end{array}$ & $\begin{array}{l}62 \\
\text { (for } A \text {. } \\
\text { triostegus; } \\
\text { McCormick, } \\
\text { 1999) }\end{array}$ & $\begin{array}{l}\text { Cytochrome-B (491) } \\
\text { Cytb9/Cytb7 } \\
\text { (DiBattista et al., 2016) }\end{array}$ & 62 \\
\hline $\begin{array}{l}\text { Centropyge } \\
\text { vrolikii } \\
\text { (DiBattista et } \\
\text { al., 2012) }\end{array}$ & $\begin{array}{l}\text { Pearlscale } \\
\text { angelfish }\end{array}$ & $\begin{array}{l}29 \\
\text { (Thresher \& } \\
\text { Brothers, } \\
\text { 1985) }\end{array}$ & $\begin{array}{l}\text { Cytochrome-B (575) } \\
\text { CLFM_FOR/ } \\
\text { CLFM_REV } \\
\text { (DiBattista et al., 2012) }\end{array}$ & 58 \\
\hline $\begin{array}{l}\text { Chaetodon } \\
\text { auriga } \\
\text { (DiBattista et } \\
\text { al., 2015) }\end{array}$ & $\begin{array}{l}\text { Threadfin } \\
\text { butterflyfish }\end{array}$ & $\begin{array}{l}48 \\
\text { (Wilson \& } \\
\text { McCormick, } \\
1999 \text { ) }\end{array}$ & $\begin{array}{l}\text { Cytochrome-B (668) } \\
\text { Cytb9/Cytb7 } \\
\text { (DiBattista et al., 2013) }\end{array}$ & 56 \\
\hline $\begin{array}{l}\text { Chaetodon } \\
\text { lunulatus } \\
\text { (Waldrop et } \\
\text { al., 2016) }\end{array}$ & $\begin{array}{l}\text { Oval } \\
\text { butterflyfish }\end{array}$ & $\begin{array}{l}35 \\
\text { (Soeparno et } \\
\text { al., 2012) }\end{array}$ & $\begin{array}{l}\text { Cytochrome-B (605) } \\
\text { Cytb9/Cytb7 } \\
\text { (Waldrop et al., 2016) }\end{array}$ & 50 \\
\hline $\begin{array}{l}\text { Ctenochaetus } \\
\text { striatus }\end{array}$ & $\begin{array}{l}\text { Striated } \\
\text { surgeonfish }\end{array}$ & $\begin{array}{l}59 \\
\text { (Wilson \& }\end{array}$ & $\begin{array}{l}\text { Control Region (316) } \\
\text { CR-A/CR-E }\end{array}$ & 50 \\
\hline
\end{tabular}




\begin{tabular}{|c|c|c|c|c|}
\hline & & $\begin{array}{l}\text { McCormick, } \\
\text { 1999) }\end{array}$ & (Lee et al., 1995) & \\
\hline $\begin{array}{l}\text { Dascyllus } \\
\text { aruanus } \\
\text { (Liu et al., } \\
2014 \text { ) }\end{array}$ & $\begin{array}{l}\text { Whitetail } \\
\text { dascyllus }\end{array}$ & $\begin{array}{l}26 \\
\text { (Thresher, } \\
\text { Colin \& Bell, } \\
\text { 1989) }\end{array}$ & $\begin{array}{l}\text { Cytochrome-B (1058) } \\
\text { GluDG-L/ } \\
\text { H16460 } \\
\text { (Palumbi et al., 1991) }\end{array}$ & 56 \\
\hline $\begin{array}{l}\text { Lutjanus } \\
\text { kasmira } \\
\text { (Gaither et al., } \\
\text { 2010) }\end{array}$ & $\begin{array}{l}\text { Bluestripe } \\
\text { snapper }\end{array}$ & $\begin{array}{l}60 \\
(\text { Baensch, } \\
2021)\end{array}$ & $\begin{array}{l}\text { Cytochrome-B (446) } \\
\text { Cytb9/Cytb7 } \\
\text { (DiBattista et al., 2013) }\end{array}$ & 48 \\
\hline $\begin{array}{l}\text { Nerita plicata } \\
\text { (Crandall et } \\
\text { al., 2008) }\end{array}$ & $\begin{array}{l}\text { Whorled } \\
\text { nerite }\end{array}$ & $\begin{array}{l}\sim 180 \\
\text { (Underwood, } \\
1978 \text { ) }\end{array}$ & $\begin{array}{l}\text { Cytochrome Oxidase I (613) } \\
\text { LCO-1490/ } \\
\text { HCO-1498 } \\
\text { (Folmer et al., 1994) }\end{array}$ & 50 \\
\hline $\begin{array}{l}\text { Pomacentrus } \\
\text { coelestis } \\
\text { (Liu et al., } \\
\text { 2012) }\end{array}$ & $\begin{array}{l}\text { Neon } \\
\text { damselfish }\end{array}$ & $\begin{array}{l}39 \\
\text { (Wilson \& } \\
\text { McCormick, } \\
\text { 1999) }\end{array}$ & $\begin{array}{l}\text { Control Region (337) } \\
\text { CR-A/CR-E } \\
\text { (Lee et al., 1995) }\end{array}$ & 50 \\
\hline
\end{tabular}

3 


\section{Table 2 (on next page)}

Genetic diversity statistics including haplotype diversity (h), nucleotide diversity $(\pi)$ and Fu's FS for each sampled Dongsha population in comparison to regional means.

Significant deviations from regional means are noted at $p<0.05\left(^{*}\right)$ and $p<0.01$ (**

Significant deviations from regional means are noted at $p<0.05\left(^{*}\right)$ and $p<0.01\left(^{* *}\right)$.

Significantly low FS values (compared to neutral coalescent simulations) at $p<0.02$ are denoted in bold. 
Table 2. Genetic diversity statistics including haplotype diversity $(\mathrm{h})$, nucleotide diversity $(\pi)$ and Fu's $\mathrm{F}_{\mathrm{S}}$ for each sampled Dongsha population in comparison to regional means. Significant deviations from regional means are noted at $p<0.05(*)$ and $p<0.01(* *)$.

3 Significantly low $\mathrm{F}_{\mathrm{S}}$ values (compared to neutral coalescent simulations) at $\mathrm{p}<0.02$ are denoted in bold.

4

\begin{tabular}{|l|c|c|c|c|c|c|c|c|c|c|}
\hline Species & $\begin{array}{c}\text { Dongsha } \\
\mathrm{N}\end{array}$ & \# Haplotypes & $\begin{array}{c}\text { Private } \\
\text { Haplotypes }\end{array}$ & $\begin{array}{c}\% \\
\text { Private }\end{array}$ & $\begin{array}{c}\text { Regional } \\
\text { Mean \% } \\
\text { Private }\end{array}$ & $\mathrm{h}$ & $\begin{array}{c}\text { Regional } \\
\text { Mean h }\end{array}$ & $\begin{array}{c}\pi \\
\text { Megional } \\
\text { Mean } \pi\end{array}$ & $\mathrm{F}_{\mathrm{s}}$ \\
\hline A. japonicus & 14 & 9 & 3 & 21.43 & 12.96 & 0.88 & 0.86 & 0.006 & 0.004 & $\mathbf{- 3 . 5 3}$ \\
\hline C. auriga & 28 & 6 & 2 & 7.14 & 7.06 & 0.51 & 0.56 & 0.001 & 0.001 & -4.16 \\
\hline C. lunulatus & 19 & 4 & 1 & 5.26 & 13.92 & 0.56 & 0.66 & 0.004 & 0.005 & 2.19 \\
\hline C. striatus & 26 & 24 & 21 & 80.77 & 75.03 & 0.99 & 0.99 & 0.025 & 0.023 & $\mathbf{- 1 5 . 4 4}$ \\
\hline C. vrolikii & 24 & 12 & 9 & 37.50 & 29.37 & 0.79 & 0.80 & 0.003 & 0.003 & $\mathbf{- 7 . 4 5}$ \\
\hline D. aruanus & 44 & 13 & 5 & 11.36 & 14.63 & 0.79 & 0.75 & 0.002 & 0.002 & -5.19 \\
\hline L. kasmira & 6 & 6 & 4 & 66.67 & $16.20^{* *}$ & $1 *$ & 0.59 & $0.007 * *$ & 0.002 & $\mathbf{- 3 . 0 3}$ \\
\hline N. plicata & 24 & 22 & 19 & 79.17 & 77.98 & 0.99 & 1.00 & 0.011 & 0.013 & $\mathbf{- 1 4 . 9 9}$ \\
\hline P. coelestis & 21 & 15 & 9 & 42.86 & $63.94 * *$ & $0.90^{* *}$ & 1.00 & $0.010^{* *}$ & 0.014 & $\mathbf{- 1 0 . 0 7}$ \\
\hline
\end{tabular}

5

6 


\section{Table 3 (on next page)}

Most probable $\left(1^{\circ}\right)$ and second most probable $\left(2^{\circ}\right)$ models and their relative probabilities for each species.

Most probable $\left(1^{\circ}\right)$ and second most probable $\left(2^{\circ}\right)$ models and their relative probabilities for each species, followed by the P-value of a one-tailed permutation t-test of the alternate hypothesis that the mean In-likelihood of the $1^{\circ}$ model is significantly higher than the mean of the $2^{\circ}$ model. Loge Bayes Factor indicates the relative probability of the best model relative to the second best model, with values greater than six indicating a strong weight of evidence (odds $>20: 1$, indicated with *), and values greater than three indicating substantial support (bolded, Kass and Raftery 1995). P-values indicate the outcome of a permutation ttest comparing the log-likelihoods of the two top-ranked models across three replicated Migrate-n runs, bolded at alpha of 0.05 . 
3 Table 3. Most probable $\left(1^{\circ}\right)$ and second most probable $\left(2^{\circ}\right)$ models and their relative probabilities for each species, followed by the P4 value of a one-tailed permutation t-test of the alternate hypothesis that the mean ln-likelihood of the $1^{\circ}$ model is significantly higher 5 than the mean of the $2^{\circ}$ model. $\log _{\mathrm{e}}$ Bayes Factor indicates the relative probability of the best model relative to the second best model, 6 with values greater than six indicating a strong weight of evidence (odds $>20: 1$, indicated with *), and values greater than three 7 indicating substantial support (bolded, Kass and Raftery 1995). P-values indicate the outcome of a permutation t-test comparing the 8 log-likelihoods of the two top-ranked models across three replicated Migrate-n runs, bolded at alpha of 0.05.

\begin{tabular}{|c|c|c|c|c|c|c|c|}
\hline Species & $1^{\circ}$ Model & $1^{\circ}$ Probability & $2^{\circ}$ Model & $2^{\circ}$ Probability & $\begin{array}{l}\mathrm{p} 1^{\circ} \text { Mean }> \\
2^{\circ} \text { Mean }\end{array}$ & $\begin{array}{l}2 \text { Ln Bayes } \\
\text { Factor } 1^{\circ} / 2^{\circ}\end{array}$ & Odds $1^{\circ}: 2^{\circ}$ \\
\hline A. japonicus & Panmixia & 0.992 & Stepping-stone & 0.008 & 0.05 & 9.55* & 118.4:1 \\
\hline C. auriga & Panmixia & 1.000 & Stepping-stone & 0.000 & 0.05 & 19.29* & $1.54 \times 10^{4}: 1$ \\
\hline C. lunulatus & Stepping-stone & 1.000 & Panmixia & 0.000 & 0.05 & 44.83* & $5.42 \times 10^{9}: 1$ \\
\hline C. striatus & Stepping-stone & 1.000 & Panmixia & 0.000 & 0.05 & 37.99* & $1.78 \times 10^{8}: 1$ \\
\hline C. vrolikii & Stepping-stone & 0.921 & Panmixia & 0.079 & 0.05 & 4.90 & 11.6:1 \\
\hline D. aruanus & Stepping-stone & 0.742 & Panmixia & 0.169 & 0.15 & 2.96 & $4.4: 1$ \\
\hline L. kasmira & Panmixia & 1.000 & Stepping-stone & 0.000 & 0.05 & 441.07* & $6.0 \times 10^{95}: 1$ \\
\hline N. plicata & Panmixia & 1.000 & Stepping-stone & 0.000 & 0.05 & $15.92 *$ & $2.86 \times 10^{3}: 1$ \\
\hline P. coelestis & Panmixia & 1.000 & Stepping-stone & 0.000 & 0.05 & 123.10* & $5.37 \times 10^{26}: 1$ \\
\hline
\end{tabular}


